\title{
OBITUARY
}

\section{Ken Been}

Ken Been, a long-standing contributor to the geotechnical literature, died in Nanaimo, British Columbia, on 13 June 2017.

Ken was born on 7 October 1953 in Cape Town, South Africa. After graduating from the University of Cape Town with a BSc in Civil Engineering, Ken won a Rhodes Scholarship to study for a DPhil, at the University of Oxford, which he was awarded in 1980. After Oxford, he joined Golder Associates where he spent his entire 36 year career initially working in Calgary before moving to Celle, Nottingham, Houston and then Halifax. His work included pipelines, sand and gravel islands, hybrid structures and spray ice islands. Ken's ability to work with others to integrate fundamental research and practical engineering made significant inroads into engineering 'difficult ground' around the world, with Ken becoming a globally recognised expert in geotechnical engineering involving reclaimed land and soft soils, in particular, for liquefied natural gas (LNG) and other onshore facilities for the oil and gas industry in North America, Africa and South America. His colleagues and co-authors regarded him as a true friend - gifted, humble, wise and a great mentor. 'Retiring' in 2015, Ken moved to Vancouver Island and, despite poor health, continued as a senior consultant until his death.

In addition to his many consulting achievements with Golder, he made lasting contributions to soil mechanics. Ken described himself as a 'soft soils man': in his DPhil research at Oxford he developed an experimental facility using X-rays that provided a continuous profile of density as a soil slurry consolidated under its own weight. Pore pressure measurements in the settling columns made it possible to observe the development of effective stress. Using a natural estuarine silty clay, Ken demonstrated that the void ratio corresponding to zero effective stress was not unique for a given soil, but depended on the initial density of the suspension. This X-ray system was a unique and hugely important experimental tool for the study of soft soil behaviour, and indeed, it continued to provide further insights for the next 20 years. The next stage of Ken's research was to show how existing theories of self-weight consolidation could be modified to include the initial conditions of the soil slurry, so that subsequent settlement and effective stress development could be predicted. The experimental and theoretical aspects of this research were brought together in his first, and widely cited, Géotechnique paper (Been \& Sills, 1981).

However, it was the behaviour of loose sands rather than loose silts where Ken contributed most to the subject. These contributions are most easily appreciated by looking back in history to understand the motivations for Ken's work. The Prudhoe Bay oilfield on the north coast of Alaska produces about a third of the oil for the USA and has done so since 1977. The geological conditions of Prudhoe Bay were thought to extend across the border into the Canadian Beaufort Shelf, and with potentially equally vast resources. The 1980s saw, as Canadian policy, about C\$2 billion (at current exchange rates) committed to exploring this offshore shelf. But there was a catch: the Beaufort Sea is ice-covered for about nine months of the year, the ice can be several metres thick and the ice moves. Conventional exploration drill-ships were not a viable option. The Canadian oil industry met the challenge by constructing artificial islands

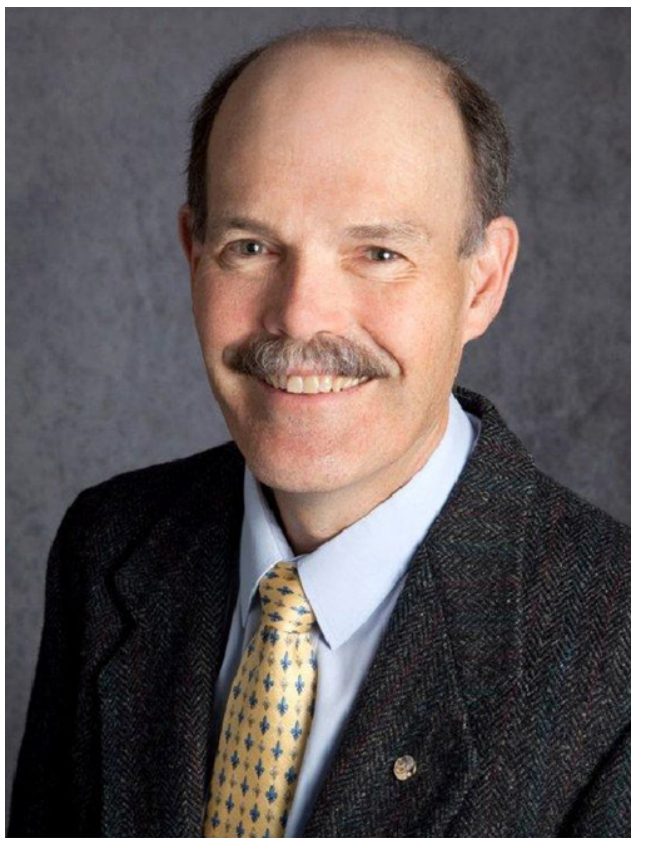

Fig. 1. Ken Been (1953-2017)

(in water depths of as much as $45 \mathrm{~m}$ ), using hydraulically placed sand during the short summer open-water season, and which then provided the working space for winterised, but otherwise conventional, exploration drilling over the winter. This then led to a basic engineering quandary where practical construction met fundamental soil behaviour - hydraulic filling had been a common construction method for earthfill dams in North America during the late 1800s to early 1900s, but they had such a history of liquefaction failures that undensified hydraulic fills were abandoned. Yet the oil industry was now about to use this same construction method, and in situations where the loads on a platform as the ice moved could far exceed those of a severe earthquake. What to do?

The Canadian industry turned to the concept pioneered by the Corps of Engineers at Franklin Falls dam (New Hampshire) in 1935. Franklin Falls was the first dam designed and constructed to resist liquefaction, the central principle being that, since loose soils contract while dense ones dilate, practical engineering must ensure that all fills are denser than the void ratio that separates dilative (strong) from contractive (liquefiable) behaviour - reasonably termed the critical void ratio in 1935, as it was truly critical to the behaviour of hydraulic fills. However, although the concept of a dividing dilative-contractive boundary is easy to understand, the difficulty is measuring what that critical void ratio is - which is in part why the critical void ratio slipped from geotechnical practice. Ken led all aspects of the required testing to resurrect the critical void ratio approach (from state-of-the art triaxial testing through to the world's largest cone penetration test (CPT) calibration chamber) for all of the oil companies operating in the Canadian arctic, allowing confident use of the methodology for safe offshore construction. Three important contributions to soil mechanics came out of this work. 
The most influential of these contributions came about from the testing to determine the critical state locus (CSL) of the various sands being used for offshore construction. Although CSLs were reasonably defined for each of these sands, a worry was that the peak strengths simply did not fit expected trends - but with nothing obviously wrong in any test. This then became a 'good consulting' moment where plotting the void ratio offset of a test from its $\mathrm{CSL}$ - the 'state parameter' - produced a pleasing unification of an otherwise very scattered body of data. John Burland heard about this work, and invited a contribution to Géotechnique: 'A state parameter for sands' (Been \& Jefferies, 1985). In the 30 years since then (and it remains one of Géotechnique's most cited papers) the state parameter approach has progressed to the situation where the recent US National Academies publication State of the art and practice in the assessment of earthquake-induced soil liquefaction (NASEM, 2016) sees the state parameter as now so widely known and established that it no longer needs attribution.

The simplicity of the state parameter, and its popularity with practical engineers, arguably obscures its greater importance. As readers of Géotechnique know, a legacy of the work at Franklin Falls' dam, some 25 years later, is the theory of soil behaviour known as 'critical state soil mechanics' (CSSM). CSSM is often (but wrongly) associated with a particular soil model: Cam Clay. Cam Clay was the pinnacle, in around 1970, of a thread of understanding of soil behaviour that started in 1885 , and elegantly linked the soil's void ratio to its mechanical behaviour. But, by about 1975, it was realised that Cam Clay (either variant) was of negligible value for most soils encountered in geotechnical practice; this realisation was used as sufficient justification, at least in North America, for many academics to exclude CSSM from taught geotechnical engineering. The linking of soil strength (also known as the Hvorslev surface) to the CSL by the state parameter led to an almost explosion of new constitutive contributions (by others) from the early 1990s. A more general form of CSSM, using this linkage to the Hvorslev surface, now dominates current understanding of soil behaviour. Thus this thread of theoretical soil mechanics that includes Reynolds, Casagrande, Taylor, Bishop, Drucker, Gibson, Henkel, Schofield, Wroth, Roscoe, Burland and Castro now has an additional name: Been.

The two further contributions were related to the state parameter, and illustrate a different side to Ken's character. The original 1985 contribution was a 'laboratory' paper in that it presumed knowledge of void ratio - but that knowledge is the missing factor for the practical engineer when assessing a sand deposit. The CPT's repeatability, and an existing database of calibration chamber tests, made it the obvious in situ test to adopt. But although chamber testing existed, the critical state line (CSL) for the soils used in those calibration tests did not. Ken reached out to universities and companies around the world to obtain both detailed chamber data and soil samples for further testing, thus developing a methodology for obtaining the state parameter from the CPT that is documented in two Géotechnique papers (Been et al., 1986, 1987); the list of people and organisations acknowledged in these two papers is testament to both Ken's diplomatic skills and his enthusiasm for links with other researchers and engineers worldwide. Ken then addressed the uniqueness of the CSL with what remains the definitive, and widely cited, contribution of Been et al. (1991). Apart from these highlighted contributions, Ken contributed to the geotechnical literature with more than 70 clearly presented papers (written with a wide group of co-authors) and co-authorship of a book on CSSM.
Ken was always enthusiastic about life and enjoyed golf, bird photography and sailing (including a trans-Atlantic trip with three Golder colleagues for 'team building'), but his passion for engineering shone through. He was active in the professional community, particularly in committees related to offshore construction (chairing both the Artificial Islands Technical Panel and the Canadian Standards Association Technical Committee on Foundations for Offshore Structures). Diagnosed with cancer in 2002, and given a bleak prognosis, Ken remained cheerful, optimistic and determined to keep working and living. This continued to the end, with Been (2016) being a keynote lecture that he delivered by video, to great acclaim, as he was not well enough to travel to the conference. This particular paper summarises and synthesises many of Ken's earlier contributions and is a public-domain publication downloadable from the International Society for Soil Mechanics and Geotechnical Engineering.

Ken is survived by his wife, Fiona, and sons Daniel and Steven.

M. Jefferies, formerly Gulf Canada Resources, Canada D. Reades, Golder Associates, Canada G. Sills, University of Oxford, UK S. Jefferis, Environmental Geotechnics, UK

\section{REFERENCES}

Been, K. (2016). Characterizing mine tailings for geotechnical design. Aust. Geomech. J. 50, No. 4, 59-78. Also published by ISSMFE as a free download, see www.issmge.org/uploads/ publications/25/26/ISC5_003.pdf.

Been, K. \& Jefferies, M. G. (1985). A state parameter for sands. Géotechnique 35, No. 2, 99-112, http://dx.doi.org/10.1680/geot. 1985.35.2.99. Reply to discussion: Géotechnique 36, No. 1, 123-132 (1986), http://dx.doi.org/10.1680/geot.1986.36.1.123.

Been, K. \& Sills, G. C. (1981). Self-weight consolidation of soft soils - an experimental and theoretical study. Géotechnique 31, No. 4, 519-535, http://dx.doi.org/10.1680/geot.1981.31.4.519. Reply to discussion: Géotechnique 32, No. 3, 284-285 (1982), http://dx.doi.org/10.1680/geot.1982.32.3.283a.

Been, K., Crooks, J. H. A., Becker, D. E. \& Jefferies, M. G. (1986). The cone penetration test in sands: part 1, state parameter interpretation. Géotechnique 36, No. 2, 239-249, http://dx.doi. org/10.1680/geot.1986.36.2.239.

Been, K., Jefferies, M. G., Crooks, J. H. A. \& Rothenburg, L. (1987). The cone penetration test in sands: part II, general inference of state. Géotechnique 37, No. 3, 285-299, http://dx.doi.org/ 10.1680/geot.1987.37.3.285.

Been, K., Jefferies, M. G. \& Hachey, J. (1991). The critical state of sands. Géotechnique 41, No. 3, 365-381, http://dx.doi.org/ 10.1680/geot.1991.41.3.365. Reply to discussion: Géotechnique 42, No. 4, 655-663 (1992), http://dx.doi.org/10.1680/geot.1992. 42.4.655.

NASEM (National Academies of Sciences, Engineering, and Medicine) (2016). State of the art and practice in the assessment of earthquake-induced soil liquefaction and its consequences. Washington, DC, USA: National Academies Press.

\section{BIBLIOGRAPHY}

Becker, D. E., Crooks, J. H. A., Been, K. \& Jefferies, M. G. (1987c). Work as a criterion for determining in situ and yield stresses in clays. Can. Geotech. J. 24, No. 4, 549-564, http://dx.doi.org/ 10.1139/T87-070. Replies to discussion: Can. Geotech. J. 25, No. 4, 848-850, (1988), http://dx.doi.org/10.1139/T88-097 and Can. Geotech. J. 26, No. 2, 327-328 (1989).

Becker, D. E., Jefferies, M. G., Crooks, J. H. A. \& Been, K. (2006). Geology, characterization, and properties of Beaufort Sea clays. In Characterisation and engineering properties of natural soils (eds T. S. Tan, K. K. Phoon, D. W. Hight \& S. Leroueil), pp. 1855-1891. Boca Raton, FL, USA: CRC Press (Taylor \& Francis).

Been, K. (1980). Stress-strain behaviour of a cohesive soil deposited under water. DPhil thesis, Oxford University, Oxford, UK. 
Been, K. (1981). Non destructive soil bulk density measurements by X-ray attenuation. ASTM Geotech. Testing J. 4, No. 4, 169-176.

Been, K. (1990). Mechanisms of failure and soil deformation during scouring. In Proceedings of the workshop on ice scouring and the design of offshore pipelines (ed. J. I. Clark), pp. 179-191. St John's, NL, Canada: C-CORE.

Been, K. (1994). Special investigations required for foundations of offshore structures. Proceedings of the 13th international conference on soil mechanics and foundation engineering, New Delhi, India, vol. 5, pp. 297-298.

Been, K. (1999). The critical state line and its application to soil liquefaction. In Physics and mechanics of soil liquefaction (eds P. V. Lade and J. A. Yamamuro), pp 195-204. Rotterdam, the Netherlands: Balkema.

Been, K. \& Jefferies, M. G. (1993a). Towards systematic CPT interpretation. In Proceedings of the Wroth memorial symposium, predictive soil mechanics (eds G. T. Houlsby and A. N. Schofield), pp. 121-134. London, UK: Thomas Telford.

Been, K. \& Jefferies, M. G. (1993b). Determination of sand strength for limit state design. Proceedings of the international symposium on limit state design in geotechnical engineering, Copenhagen, Denmark, vol. 1, pp. 101-110.

Been, K. \& Jefferies, M. G. (2004). Stress-dilatancy in very loose sand. Can. Geotech. J. 41, No. 5, 972-989, http://dx.doi.org/ 10.1139/T04-038.

Been, K. \& Kosar, K. M. (1991). Hydraulic fracture simulations in a calibration chamber. Proceedings of the 1 st international symposium on calibration chamber testing/ISOCCT1, Potsdam, New York, NY, USA, pp. 67-77.

Been, K. \& Li, A. L. (2009). Soil liquefaction and paste tailings. In Paste 2009, proceedings of the 12th international seminar on paste and thickened tailings (eds R. Jewell, A. Fourie, S. Barrera and J. Wiertz), pp. 281-290. Perth, Australia: Australian Centre for Geomechanics.

Been, K. \& Ritchie, D. (2008). Designing mine tailings disposal for liquefaction. Proceedings of the 4th international mining and industrial waste management conference, Rustenburg, South Africa.

Been, K., Crooks, J. H. A. \& Becker, D. E. (1985). Geotechnical design of caisson islands. Proceedings of the ASCE specialty conference on civil engineering in the arctic offshore, San Francisco, CA, USA, pp. 1206-1214.

Been, K., Conlin, B. H., Crooks, J. H. A., Fitzpatrick, S. W., Jefferies, M. G., Rogers, B. T. \& Shinde, S. (1987b). Discussion on 'Back analysis of the Nerlerk berm liquefaction slides'. Can. Geotech. J. 24, No. 1, 170-179.

Been, K., Lingnau, B. E., Crooks, J. H. A. \& Leach, B. (1987c). Cone penetration test calibration for Erksak (Beaufort Sea) sand. Can. Geotech. J. 24, No. 4, 601-610, http://dx.doi.org/ 10.1139/T87-074. Reply to discussion: Can. Geotech. J. 26, No. 1, 177-182 (1989).

Been, K., Crooks, J. H. A. \& Rothenburg, L. (1988a). A critical appraisal of CPT calibration chamber tests. Proceedings of Ist international symposium on penetration testing, Orlando, FL, USA, vol. 2, pp. 651-660.

Been, K., Crooks, J. H. A. \& Jefferies M. G. (1988b). Interpretation of material state from the CPT in sands and clays. Proceedings of the ICE conference on penetration testing in the UK, Birmingham, UK, pp. 89-92.

Been, K., Crooks, J. H. A., Conlin, B. H. \& Horsfield, D. (1988c). Liquefaction of hydraulically placed sand fills. Proceedings of the ASCE specialty conference on hydraulic fill structures, Fort Collins, CO, USA, pp. 573-590.

Been, K., Horsfield, D. \& Jefferies, M. G. (1989a). Discussion: Calibration chamber tests of a cone penetrometer in sand. Géotechnique 39, No. 4, 728-729, http://dx.doi.org/10.1680/ geot.1989.39.4.727.

Been, K., Miller, I. \& Crooks, J. H. A. (1989b). Performance assessment in geotechnical design of Arctic offshore structures. Proceedings of the 8th joint international conference on offshore mechanics and polar engineering, The Hague, the Netherlands, vol. IV, pp. 113-123.

Been, K., Kosar, K., Hachey, J. E., Rogers, B. T. \& Palmer, A. C. (1990). Ice scour models. Proceedings of the 9th international conference on offshore mechanics and arctic engineering, Houston, TX, USA, vol. V, pp. 179-188.
Been, K., Clark, J. I. \& Livingstone, W. R. (1993a). Verification and calibration studies for the new CAN/CSA-S472 foundations of offshore structures. Can. Geotech. J. 30, No. 3, 515-525, http://dx.doi.org/10.1139/T93-044.

Been, K., Jefferies, M. G., Hachey, J. E. \& Rothenburg, L. (1993b). Numerical prediction for model-2. In Proceedings of the international conference on the verification of numerical procedures for the analysis of soil liquefaction problems, vol. 1: experimental results and numerical predictions (Class $A \& B$ ) (eds K. Arulanandan and R. F. Scott), pp. 331-341. Rotterdam, the Netherlands: Balkema.

Been, K., Rogers, B. T. \& Hachey, J. E. (1993c). Probability of failure and safety factor of CRI production structure in Beaufort Sea. Proceedings of the 4th Canadian marine geotechnical conference, St John's, NL, Canada, pp. 276-291.

Been, K., Chakrabarty, C. \& Wei, L. (1995). Discrete fracture modelling of reservoirs. Proceedings of the EAPG workshop on faults and fractures - effects on reservoir properties and performance, Glasgow, UK.

Been, K., Brown, E. T. \& Hepworth, N. (2002). Liquefaction potential of paste fill at Neves Corvo mine, Portugal. Trans. Instn Min. Metall., Section A: J. Min. Technol. 111, No. 1, 47-58.

Been, K., Sancio, R. B., Ahrabian, D., Van Kesteren, W., Croasdale, K. \& Palmer, A. C. (2008). Subscour displacement in clays from physical model tests. Proceedings of the 7 th international pipeline conference, Calgary, Canada, vol. 4, pp. 239-245, paper no. IPC-64186, http://dx.doi.org/10.1115/IPC2008-64186.

Been, K., Qunionez, A. \& Sancio R. B. (2010). Interpretation of the CPT in engineering practice. Keynote Lecture. Proceedings of CPT'10, 2nd international symposium on cone penetration testing, Huntington Beach, CA, USA, pp. 27-45.

Been, K., Fredj, A. \& Comfort, G. (2011). Pipeline strains in soft clay backfill subject to ice gouging. J. Pipeline Engng, 10, No. 2, 87-98.

Been, K., Peek, R., Croasdale, K. \& Verlaan, P. (2013). Subscour displacements for pipeline design: state of practice for Kashagan Project. Proceedings of the 22nd international conference on port and ocean engineering under arctic conditions, Espoo, Finland, paper no. POAC-189.

Croasdale, K., Comfort, G. \& Been, K. (2005). Investigation of ice limits to ice gouging. Proceedings of the 18th international conference on port and ocean engineering under arctic conditions, Potsdam, NY, USA, vol. 1, pp. 23-32.

Crooks, J. H. A., Jefferies, M. G., Becker, D. E. \& Been, K. (1986a). Geotechnical properties of Beaufort Sea clays. Proceedings of the 3rd Canadian conference on marine geotechnical engineering, St John's, NL, Canada, pp. 329-346.

Crooks, J. H. A., Been, K., Mickleborough, B. W. \& Dean, J. P. (1986b). An embankment failure on soft fissured clay. Can. Geotech. J. 23, No. 4, 528-540.

Crooks, J. H. A., Been, K., Becker, D. E. \& Jefferies, M. G. (1988). CPT interpretation in clays. Proceedings of the 1st international symposium on penetration testing, Orlando, FL, USA, vol. 2, pp. $715-722$.

Dershowitz, W. J., Hurley, N. \& Been, K. (1992). Stochastic discrete fracture modelling of heterogeneous and fractured reservoirs. In ECMOR III: proceedings of the third European conference on the mathematics of oil recovery (eds M. A. Christie, F. V. Da Silva, C. L. Farmer, O. Guillon, Z. E. Heinemann, P. Lemonnier, J. M. M. Regtien and E. van Spronsen), pp. 119-136. Delft, the Netherlands: Delft University Press.

Elliot, G., Ospina, R. \& Been, K. (2010). Static liquefaction of hydraulic fills: implications for design, construction, operation and safety of coal ash impoundments. Proceedings of the $A S D S O S E$ region conference - dam safety in the southeast, Charleston, WV, USA.

Fredj, A., Comfort, G. \& Been, K. (2011). The forces required to produce seabed gouges. Proceedings of the 21st international conference on ports and oceans under arctic conditions, Montréal, Canada, paper POAC11-185.

Jefferies, M. G. \& Been, K. (1987). Use of critical state representations of sand in the method of stress characteristics. Can. Geotech. J. 24, No. 3, 441-446, http://dx.doi.org/10.1139/T87-054.

Jefferies, M. G. \& Been, K. (1995). Cone factors in sand. Proceedings of international symposium on cone penetration testing - CPT '95, Linkoping, Sweden, vol. 2, pp. 187-193. 
Jefferies, M. G. \& Been, K. (2000). Implications for critical state theory from isotropic compression of sand. Géotechnique 50, No. 4, 419-429, http://dx.doi.org/10.1680/geot.2000. 50.4.419.

Jefferies, M. \& Been, K. (2004). Discussion: Non-uniqueness of flow liquefaction line for loose sand. Geotechnique 54, No. 1, 66-68, http://dx.doi.org/10.1680/geot.2004.54.1.66.

Jefferies, M. \& Been, K. (2006). Soil liquefaction - a critical state approach, 2nd edn. Abingdon, UK: Taylor \& Francis.

Jefferies, M. G., Jonsson, L. \& Been, K. (1987). Experience with measurement of horizontal geostatic stress in sand during cone penetration test profiling. Géotechnique 37, No. 4, 483-498, http://dx.doi.org/10.1680/geot.1987.37.4.483.

Jefferies, M. G., Rogers, B. T., Griffin, K. M. \& Been, K. (1988). Characterisation of sandfills with the cone penetration test. Proceedings of the ICE conference on penetration testing in the UK, Birmingham, UK, pp. 73-76.

Jefferies, M. G., Been, K. \& Olivera, R. (2012). Discussion on 'Evaluation of static liquefaction potential of silty sand slopes' by Lade, PV and Yamamuro, JA. Can. Geotech. J. 49, No. 6, 746-750. http://dx.doi.org/10.1139/T2012-039.

Jefferies, M. G., Shuttle, D. A. \& Been, K. (2015). Principal stress rotation as cause of cyclic mobility. Geotech. Res. 2, No. 2, 66-96, http://dx.doi.org/10.1680/gr.15.00002.

Ji, J. Z., Tse, L., Been, K. \& Quiñonez, A. (2008). A 3D soil-structure interaction analysis for a piled raft foundation in highly compressible soils. In GeoEdmonton'08: 61st Canadian geotechnical conference and 9th joint CGS/IAH-CNC groundwater conference: conference proceedings, vol. 1, pp. 89-96. Edmonton, AB, Canada: GeoEdmonton'08 (for Canadian Geotechnical Society).

Kenny, S., Palmer, A. C. \& Been K. (2007). Design challenges for offshore pipelines in Arctic environments. Proceedings of the $3 r d$ annual IBC energy conference offshore oil and gas in arctic and cold waters, Stavanger, Norway.

Kosar, K. M. \& Been, K. (1989). Large scale laboratory fracture test in oil sands. Proceedings of the 40th annual technical meeting, Petroleum Society of the CIM, Banff, AB, Canada, paper 89-40-84.

Kosar, K. M. \& Been, K. (1991). The effects of geomechanical behaviour on in-situ recovery processes in oil sands reservoirs. Proceedings of the 5th international conference on heavy crude and tar sands, Caracas, Venezuela, vol. 3, pp. 307-312.

Li, A. L., Been, K., Ritchie, D. \& Welch, D. (2009). Stability of large thickened, non-segregated tailings slopes. In Paste 2009, proceedings of the 12th international seminar on paste and thickened tailings (eds R. Jewell, A. Fourie, S. Barrera and J. Wiertz), pp. 311-312. Perth, Australia: Australian Centre for Geomechanics.

Lowings, M., Been, K., Krzewinski, T. \& Musial, M. (2008). Environmental and engineering issues related to onshore/offshore pipelines in changing Arctic regions. Proceedings of the IBC energy conference: arctic oil and gas 2008, Oslo, Norway.

McCarron, W. O. \& Been, K. (1990). Response of a Beaufort Sea clay to monotonic and cyclic loading. Proceedings of the 9th international conference on offshore mechanics and arctic engineering, Houston, TX, USA, vol. IV, pp. 329-336.
Palmer, A. C. \& Been, K. (2011). Pipeline geohazards for Arctic condition. In Deepwater foundations and pipeline geomechanics (ed. W. O. McCarron), pp. 171-188. Plantation, FL, USA: J. Ross Publishing.

Palmer, A. C., Konuk, I., Love, J., Been, K. \& Comfort, G. (1989). Ice scour mechanisms. Proceedings of the 10th international conference on port and ocean engineering under arctic conditions, Lulea, Sweden, vol. 1, pp. 123-132.

Palmer, A. C., Konuk, I., Comfort, G. \& Been, K. (1990). Ice gouging and the safety of marine pipelines. Proceedings of the offshore technology conference, Houston, TX, USA, paper OTC 6371, pp. 235-243.

Palmer, A. C., Konuk, I., Niederoda, A. W., Been, K. \& Croasdale, K. R. (2005). Arctic seabed ice gouging and large sub-gouge deformations. In Frontiers in offshore geotechnics (eds S. Gourvenec and M. Cassidy), pp. 645-650. Boca Raton, FL, USA: CRC Press.

Paulin, M. J., Kenny, S. P., Palmer, A. C., Been, K. \& Caines, J. V. M. (2008). Offshore pipelines in cold regions - environmental loadings and geotechnical considerations. Proceedings of ICETECH08, Banff, AB, Canada, pp. 406-413.

Rogers, B. T. \& Been, K. (1990). Derivation of Nk values for CPT interpretation; gulf Amauligak pipeline route. Proceedings of the workshop on offshore in-situ technique, Quebec City, QC, Canada.

Rogers, B. T., Been, K., Hardy, M. D., Johnson, G. J. \& Hachey, J. E. (1990). Re-analysis of Nerlerk B-67 berm failures. Proceedings of the 43rd Canadian geotechnical conference, Québec, Canada, vol. 1, pp. 227-237.

Sancio, R. B., Been, K. \& Lopez, J. (2011). Large scale indenter test program to measure subscour displacements. Proceedings of the 21 st international conference on ports and oceans under arctic conditions, Montréal, Canada, paper POAC11-096.

Sancio, R., Rice, A., Been, K. \& Villet, W. (2016). Seismic stability performance of a coastline slope beneath a pipeline: a case history of onshore observations for offshore application. Proceedings of the offshore technology conference, Houston, TX, USA, paper OTC-27217-MS.

Schoonbeek, I. S. S., Xin, M. X., van Kesteren, W. G. M. \& Been, K. (2006). Slip line field solutions as an approach to understand ice subgouge deformation patterns. In Proceedings of the 16th international offshore and polar engineering conference (ISOPE 2006) (eds J. S. Chung, S. W. Hong, P. W. Marshall, T. Komai and W. Koterayama), vol. 1, pp. 628-633. Cupertino, CA, USA: International Society of Offshore and Polar Engineers (ISOPE).

Sills, G. C. \& Been, K. (1998). Editorial: '50th anniversary issue'. Géotechnique 48, No. 3, 300, http://dx.doi.org/10.1680/geot. 1998.48.3.300.

Weaver, J. S., Been, K. \& Horsfield, D. W. (1997). Creep and strength tests on warm dry spray ice. Can. Geotech. J. 34, No. 1, 17-25.

Wei, L. \& Been, K. (1996). Interpretation of fracture transmissivity and flow geometry from hydraulic tests. Proceedings of Eurock'96, prediction and performance in rock mechanics and rock engineering, Torino, Italy, vol. II, pp. 1253-1260.

Wei, L., Been, K. \& Eiben, T. (1998). Quantification of geological models against interference tests using discrete fracture network techniques. Proceedings of the 2 nd IMA conference on modelling permeable rocks, Cambridge, UK. 